\title{
SOUTHERN PALESTINIAN CHRONOLOGY: TWO RADIOCARBON DATES FOR THE EARLY BRONZE AGE AT TELL EL-HESI (ISRAEL)
}

Roger W Anderson, Jr

911 9th St., Mukilteo, Washington 98275, USA. Email: rwander48@comcast.net.

ABSTRACT. Several articles reporting radiocarbon dates of Early Bronze Age (EB) material from excavations in the southern Levant have been published over the last $30 \mathrm{yr}$. The excavations conducted at Tell el-Hesi have produced material from which 2 additional ${ }^{14} \mathrm{C}$ dates have been extracted to date. The 2 samples confirm the EB dating of Field VI material and suggest EB III settlement at Hesi might be earlier than previously reported based on pottery typology.

\section{INTRODUCTION}

Radiocarbon dates of material culture found at Near Eastern archaeological sites, especially those in the southern Palestinian or Levantine area (Figure 1), have been gathered in several articles spanning almost $30 \mathrm{yr}$. The ${ }^{14} \mathrm{C}$ dates cover remains from several prehistoric and historic periods. Each of the dates adds to the corpus of material that will enable a broader reconstruction of the history of the periods and a stronger correlation between ceramic stratigraphic analysis and dating. This particular report adds to the corpus of Early Bronze Age (EB) dates, especially EB III.

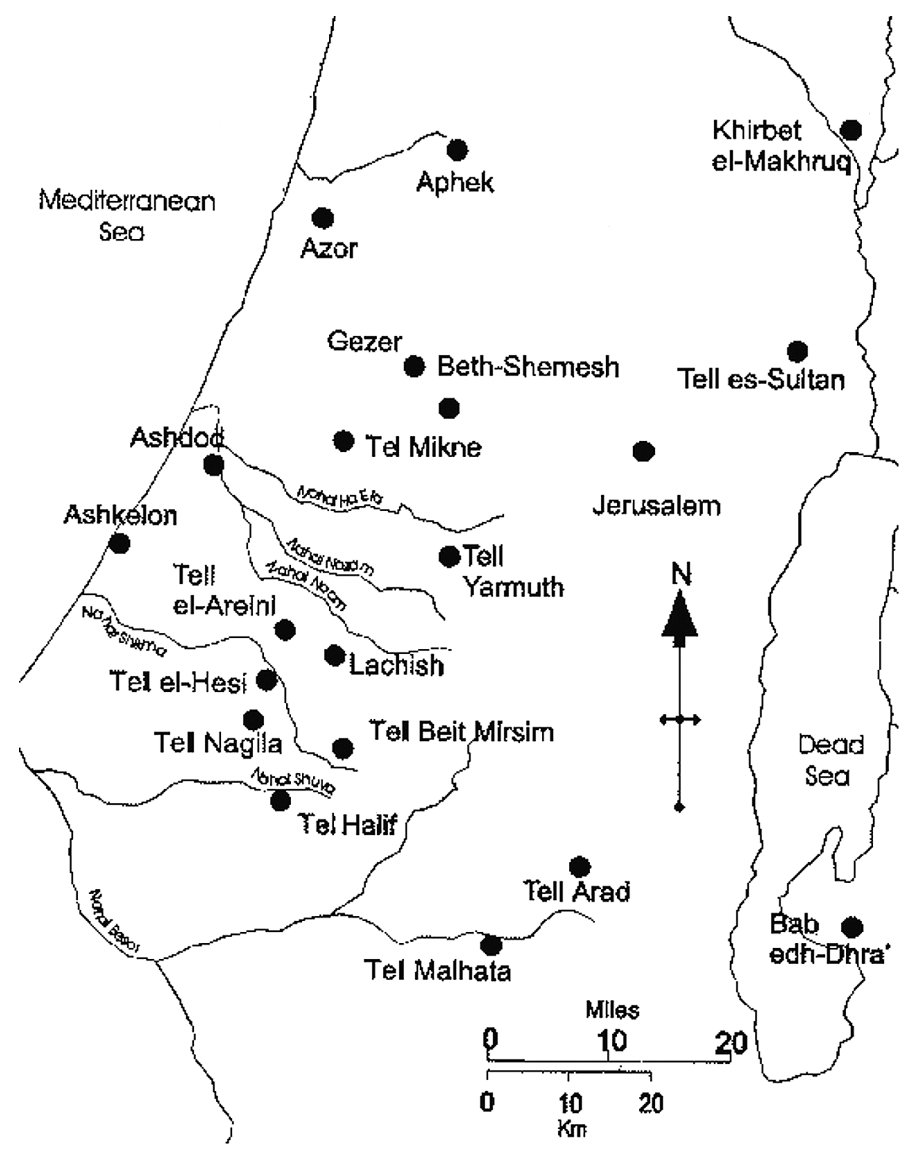

Figure 1 Some Early Bronze Age sites in southern Palestine 
The Early Bronze Age in Palestinian archaeological studies is a period of uncertain duration, but often is considered to cover the period from 3500 to 2200 BCE (see e.g. Ahlström 1993; Rast 1992). The EB is usually divided into 3 periods with approximate ranges of EB I (3500-2900 BCE), EB II (2900-2600 BCE), and EB III (2600-2200 BCE). A period frequently termed EB IV-MB I (2200-1800 BCE) is usually viewed as a transition from the EB to the Middle Bronze Age (MB). These generally accepted divisions of the EB are often put forth as progressive stages in this period of urban development.

Table 1 summarizes 8 articles listing ${ }^{14} \mathrm{C}$ dates for material culture uncovered at Palestinian sites. Each article presents the dates of ${ }^{14} \mathrm{C}$ analyses differently; some of the early articles and dates are derived from what are now considered to be less than accurate procedures. Also, some of the articles do not separate the results into the different EB periods, and some do not separate results into any archaeological period. The articles often present sites and ${ }^{14} \mathrm{C}$ results detailed in previous articles. Sometimes several samples have been analyzed from the same archaeological site and occasionally from various areas of the site and submitted in different years. The articles list 33 different sites for Palestine, including the Negev, and the dates of approximately 204 different samples. Following the general formulation of EB dates mentioned above, Table 1 summarizes these 8 articles that have published ${ }^{14} \mathrm{C}$ dates for EB Palestine.

Table 1 Summary of articles listing Early Bronze Age ${ }^{14} \mathrm{C}$ dates. All dates are BCE.

\begin{tabular}{|c|c|c|c|}
\hline Authors & EB I & EB II & EB III \\
\hline Callaway and Weinstein & 5 sites & 3 sites & 4 sites \\
\hline 1977 & $\begin{array}{l}19 \text { samples } \\
\text { range: } 4030-2920\end{array}$ & $\begin{array}{l}24 \text { samples } \\
\text { range: } 3679-2620\end{array}$ & $\begin{array}{l}12 \text { samples } \\
\text { range: } 3340-2520\end{array}$ \\
\hline \multirow{2}{*}{ Weinstein 1984} & 6 sites & 5 sites & 5 sites \\
\hline & $\begin{array}{l}25 \text { samples } \\
\text { range: } 5480-2795\end{array}$ & $\begin{array}{l}36 \text { samples } \\
\text { range: } 3810-2535\end{array}$ & $\begin{array}{l}30 \text { samples } \\
\text { range: } 3900-2305\end{array}$ \\
\hline \multirow[t]{2}{*}{ Stager 1992} & 5 sites & 4 sites & 3 sites \\
\hline & $\begin{array}{l}12 \text { samples } \\
\text { range: } 5480-2930\end{array}$ & $\begin{array}{l}42 \text { samples } \\
\text { range: } 3955-2545\end{array}$ & $\begin{array}{l}21 \text { samples } \\
\text { range: } 3955-1855\end{array}$ \\
\hline \multirow[t]{2}{*}{ Housley 1994} & 1 site & 1 site & 1 site \\
\hline & $\begin{array}{l}2 \text { samples } \\
\text { range: } 5270-4590\end{array}$ & $\begin{array}{l}6 \text { samples } \\
\text { range: } 4580-4140\end{array}$ & $\begin{array}{l}2 \text { samples } \\
\text { range: } 4130-4100\end{array}$ \\
\hline \multirow[t]{2}{*}{ Avner et al. 1994} & 4 sites & 7 sites & 8 sites \\
\hline & $\begin{array}{l}10 \text { samples } \\
\text { range: } 3690-3028\end{array}$ & $\begin{array}{l}19 \text { samples } \\
\text { range: } 3093-2355\end{array}$ & $\begin{array}{l}13 \text { samples } \\
\text { range: } 2633-1763\end{array}$ \\
\hline \multirow[t]{2}{*}{ Avner and Carmi 2001} & 5 sites & 9 sites & 10 sites \\
\hline & $\begin{array}{l}16 \text { samples } \\
\text { range: } 3520-2700\end{array}$ & $\begin{array}{l}16 \text { samples } \\
\text { range: } 2920-2300\end{array}$ & $\begin{array}{l}17 \text { samples } \\
\text { range: } 2630-2200\end{array}$ \\
\hline Bruins and van der Plicht & 1 site & 1 site & 1 site \\
\hline 2001 & $\begin{array}{l}4 \text { samples } \\
\text { range: } 3370-3030\end{array}$ & $\begin{array}{l}3 \text { samples } \\
\text { range: } 3020-2900\end{array}$ & $\begin{array}{l}1 \text { sample } \\
\text { range: } 2890-2700\end{array}$ \\
\hline Golani and Segal 2002 & $\begin{array}{l}1 \text { site } \\
17 \text { samples } \\
\text { range: } 4081-3042\end{array}$ & & \\
\hline
\end{tabular}

It is not the intention of this article to analyze all the dates, but rather to add 2 dates from the Hesi samples to the corpus of ${ }^{14} \mathrm{C}$ dates for EB Palestine. The purpose of this paper is to provide additional evidence to the ${ }^{14} \mathrm{C}$ corpus for dating EB cities and cultural remains in the southern Levant. 


\section{Site Background and Context}

Tell el-Hesi is located $23 \mathrm{~km}$ from the Mediterranean and $26 \mathrm{~km}$ east-northeast of Gaza $\left(31^{\circ} 32^{\prime} \mathrm{N}\right.$, $34^{\circ} 43^{\prime} \mathrm{E}$, or 124106 on the Israeli grid system). First excavated in 1890 by Sir William Mathew Flinders Petrie and in 1891 by Frederick Jones Bliss, current excavations began in 1969 organized by George Ernest Wright (Dahlberg and O'Connell 1989). Excavations on the southern part of the tell began in 1975 where a large EB portion of the city lay under a Muslim cemetery (Eakins 1993).

During the 1979 field season in Field VI, a significant number of seeds were discovered in an ash dump outside the city wall (Figure 2). The ash dump extended from VI.42 through VI.52 and was over $2 \mathrm{~m}$ deep (O'Connell and Rose 1980). Pockets of ash were discovered in other areas as well, but the large dump along the exterior wall was sampled since it was quite deep and was likely to contain fewer intrusions than other places where ash was discovered. The extent of the ash dump was approximately $6 \mathrm{~m}$ wide along the face of the outside wall and about $6 \mathrm{~m}$ away from the wall going to the south and diminishing in depth the further away from the wall the ash was dumped. The pottery dated to the EB throughout the ash level, with the exception of the uppermost level that was a disturbed area, probably due to weathering, intrusions by agriculturalists from several periods, early 19th century Bedouin burials, and 20th century military activities.

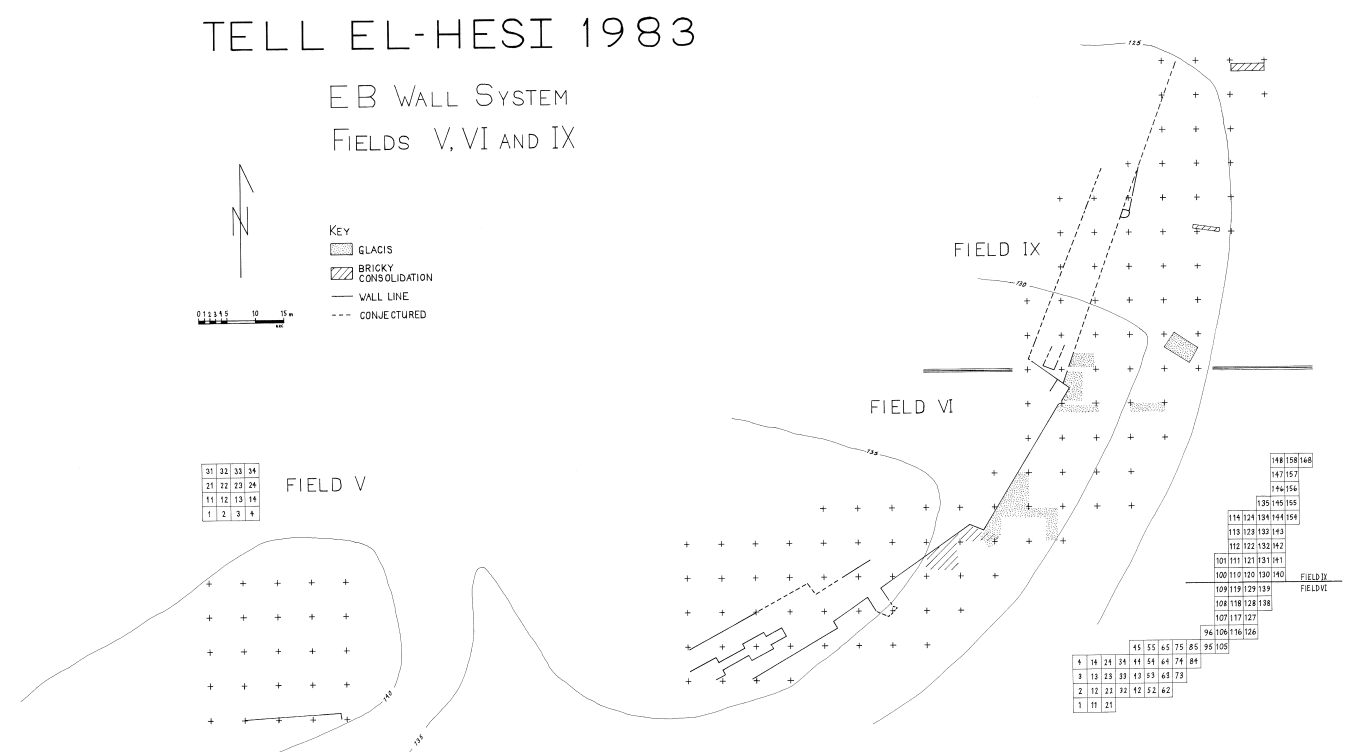

Figure 2 Early Bronze Age in fields V, VI, and IX

Two charred emmer seed samples collected from this ash level were sent to Beta Analytic Inc. (Beta) for ${ }^{14} \mathrm{C}$ analysis. One sample was slightly above the bottom of a 2-m-high ash layer in VI.52, above a hard-packed surface in a dung layer; the other sample was on the bottom level of VI. 42, on the walking surface along the wall and buttress (O'Connell and Rose 1980). Both samples were collected in guffas and taken to a botanist for flotation and analysis. The seeds used in these samples were collected during the flotation process of ash material (Stewart and Robertson 1973; see also Stewart and Robertson 1971). 


\section{RESULTS}

The results provided by Beta were detailed in printed reports. The analysis was made using accelerator mass spectrometry (AMS) standard delivery following a full pretreatment of acid/alkali/acid. Beta calculated ${ }^{14} \mathrm{C}$ age and calendar calibration following Radiocarbon Vol. 40, No. 3 (1998) calibration data and the Pretoria calibration procedure. The reports include 1- and 2- $\sigma$ dates. The Beta number appears first followed by the Hesi material cultural registry (MCR) number.

\section{Beta-147501. Tell el-Hesi 12146}

$4170 \pm 50 \mathrm{BP}$

Carbonized emmer seeds found in ash deposit outside of mud-brick wall system $\sim 1.1 \mathrm{~m}$ below the surface; several thousand seeds found in the ash layer against the wall; sample from Field VI Area 42 locus 021 . The Hesi MCR number is 12146 . The sample was collected in 1979 by the author on the walking surface next to the outer city wall and buttress in a dung lens on the surface over barren soil.

Comment: Beta reports the measured ${ }^{14} \mathrm{C}$ age as $4110 \pm 50 \mathrm{BP}$. The $1-\sigma$ calibrated dates of 2880 $2830 \mathrm{BC}$ and $2830-2650 \mathrm{BC}$ and 2- $\sigma$ dates of 2890-2590 BC are reported by Beta. These dates provide a correlation with EB III pottery horizon for the southern Levant indicating occupation of Tell el-Hesi during this period.

\section{Beta-147502. Tell el-Hesi 13611}

$4200 \pm 50 B P$

Carbonized emmer seeds found in ash deposit outside of mud-brick wall system $1.8 \mathrm{~m}$ below the surface; several thousand seeds found in the ash layer; sample from Field VI Area 52 locus 010.3. The Hesi MCR number is 13611. The sample was collected in 1979 by the author on the bottom of an ash fill against the outside city wall above a hard-packed surface in a dung lens.

Comment: Beta reports the measured ${ }^{14} \mathrm{C}$ age as $4150 \pm 50 \mathrm{BP}$. The $1-\sigma$ calibrated dates of 2890 $2860 \mathrm{BC}$ and $2810-2690 \mathrm{BC}$ and 2- $\sigma$ dates of $2900-2620 \mathrm{BC}$ are reported by Beta. These dates provide correlation with the EB III pottery horizon for the southern Levant for occupation of Hesi during this period. The results are summarized in Table 2.

Table 2 Summary of Beta Analytic reports.

\begin{tabular}{|c|c|}
\hline Beta-47501 & Beta-47502 \\
\hline $\begin{array}{l}\text { Description: carbonized emmer seeds } \\
{ }^{14} \mathrm{C} \text { age: } 4170 \pm 50\end{array}$ & $\begin{array}{l}\text { Description: carbonized emmer seeds } \\
{ }^{14} \mathrm{C} \text { age: } 4200 \pm 50\end{array}$ \\
\hline Calibration data set: intcal04.14c $\mathrm{c}^{\mathrm{a}}$ & Calibration data set: intcal04.14c $\mathrm{c}^{\mathrm{a}}$ \\
\hline $\begin{array}{l}1-\sigma \text { ranges: [start:end] relative area } \\
{[2877 \mathrm{BC}: 2847 \mathrm{BC}] 0.181105} \\
{[2844 \mathrm{BC}: 2840 \mathrm{BC}] 0.015803} \\
{[2813 \mathrm{BC}: 2692 \mathrm{BC}] 0.738347} \\
{[2689 \mathrm{BC}: 2678 \mathrm{BC}] 0.064745}\end{array}$ & $\begin{array}{l}1-\sigma \text { ranges: [start:end] relative area } \\
{[2892 \mathrm{BC}: 2852 \mathrm{BC}] 0.285065} \\
{[2812 \mathrm{BC}: 2744 \mathrm{BC}] 0.523043} \\
{[2726 \mathrm{BC}: 2696 \mathrm{BC}] 0.191892}\end{array}$ \\
\hline $\begin{array}{l}\text { 2- } \sigma \text { ranges: [start:end] relative area } \\
{[2890 \mathrm{BC}: 2619 \mathrm{BC}] 0.989064} \\
{[2606 \mathrm{BC}: 2600 \mathrm{BC}] 0.007253} \\
{[2592 \mathrm{BC}: 2589 \mathrm{BC}] 0.003683}\end{array}$ & $\begin{array}{l}\text { 2- } \sigma \text { ranges: [start:end] relative area } \\
\text { [2903 BC:2831 BC] } 0.28101 \\
\text { [2821 BC:2630 BC] } 0.71899\end{array}$ \\
\hline
\end{tabular}

${ }^{\mathrm{a}}$ Reimer et al. 2004. 


\section{DISCUSSION AND CONCLUSION}

Pottery typology has been the main indicator of chronology at Syro-Palestinian sites since Petrie (1891) and Bliss (1898) (see also Amiran 1970; Dever 1997). The first site for defining this typology as a ceramic sequence was Tell el-Hesi where Petrie began his work and Bliss continued (Herr 2002). The EB pottery found by Petrie and Bliss was an important indicator of early cultures at the site. Subsequent excavations at the site (Toombs 1990) have encountered additional EB pottery and occupation levels. The pottery chronology tradition at Tell el-Hesi continues to be studied and described by Fargo (1979), Seger (1989), and de Miroschedji (2000), reiterating chronological arguments based on an established ceramic typology for EB forms (Amiran 1970; Herr 2002).

Pierre de Miroschedji (2000) mentions that the EB assemblage at Tell el-Hesi appears to be similar to the EB IIIA period ( 2600 BCE) at Yarmuth, although "the most typical pottery published from the early excavations of Petrie in 1890 and Bliss in 1891-92 testify to an EB III B-C occupation on the main mound" (de Miroschedji 2000:336). This conclusion is indeed the case, but the pottery from Field VI is not from the main acropolis and is considered to exemplify an earlier date for the EB. Hesi staff (Rose and Toombs 1976; O'Connell et al. 1978; O'Connell and Rose 1980; Toombs 1983; Doermann and Fargo 1985) have previously provided preliminary discussions of EB remains. Additional analyses and specialized studies continue to be made by Hesi staff towards a more complete presentation of the EB material that will include pottery typologies and other analyses of remains.

Preliminary discussion has suggested that EB occupation at Hesi occurred in the middle to end of the EB III period (Toombs 1983). The ${ }^{14} \mathrm{C}$ seed samples suggest that EB settlement at Hesi might have occurred at the beginning of the EB III period or even earlier and not in the middle or end of the period. A revision in dating EB settlement at Hesi also might have ramifications for other EB sites in the region with similar ceramic repertoires. Similarly, an analysis of EB Jericho samples by Bruins and van der Plicht (2001) reports dates that are earlier than those posited by Kenyon based on pottery analysis.

The 2 samples sent from the Tell el-Hesi staff to Beta provide part of the additional analyses needed to confirm the EB occupation dates at Hesi. The dates of the 2 samples as calibrated by Beta are 2890-2590 and 2900-2620 BCE. These dates confirm the EB III period for the pottery from Field VI and also possibly indicate an earlier date for settlement for Field VI than from the main acropolis at the larger mound (Fields I and III) as suggested by de Miroschedji. Further analyses might be able to provide additional information and help in determining if the "traditional" dates for EB III might need to be revised (Braun 2001).

For the moment, the ${ }^{14} \mathrm{C}$ dates for these 2 samples confirm the EB dates for occupation in the lower city at Tell el-Hesi. These dates also provide additional clues about the pottery chronology for southern Levantine pottery and interconnections in the immediate region (Avner et al. 1994; Phillips 1994) and the larger area (Smith 1965; Hennessy 1967; Esse 1991).

The EB ${ }^{14} \mathrm{C}$ dates from southern Palestine provide material for a historical reconstruction of the period. However, the use of ${ }^{14} \mathrm{C}$ dates as "yardsticks" (van der Plicht and Bruins 2001) and a "unifying" foundation (Bruins 2001) must be used with caution since laboratory errors (Mazar 2004) and length of standard deviations (Burton and Levy 2001) are concerns for evaluating the accuracy of the ${ }^{14} \mathrm{C}$ dating processes and results. Yet, the growing number of ${ }^{14} \mathrm{C}$ dates for adjacent areas, such as the Negev and Sinai, provide additional material for historical reconstruction. The new evidence from Tell el-Hesi provides further data building a broader and more solid base for such a reconstruc- 
tion. The ${ }^{14} \mathrm{C}$ dates from Hesi and Jericho (Bruins and van der Plicht 2001) also suggest that the pottery chronology dates for EB III, and possibly for the entire Early Bronze Age, in the southern Levant might need to be revised to reflect earlier dates than are usually presented.

\section{ACKNOWLEDGMENTS}

The author thanks all of the volunteers who worked in Field VI from 1977 through 1983, especially those in areas 42, 52, 53, and 64 in 1979. Also, the author thanks J A Blakely, J R Spencer, and L E Toombs for reading a draft of the paper. The dating of the samples was done by Beta Analytic Inc. in Miami, Florida (USA) and paid for by the Board of Directors of the Joint Archaeological Expedition to Tell el-Hesi. Illustrations were provided by Hesi staff. The author also thanks Tim Jull for his help with Calib 5.1.

\section{REFERENCES}

Ahlström GW. 1993. The History of Ancient Palestine. Minneapolis: Fortress Press. 990 p.

Amiran R. 1970. Ancient Pottery of the Holy Land. New Brunswick: Rutgers University Press. 305 p.

Avner U, Carmi I. 2001. Settlement patterns in the southern Levant deserts during the 6th-3rd millennia BC: a revision based on ${ }^{14} \mathrm{C}$ dating. Radiocarbon $43(3)$ : 1203-16.

Avner U, Carmi I, Segal D. 1994. Neolithic to Bronze Age settlement of the Negev and Sinai in light of radiocarbon dating: a view from the southern Negev. In: Bar-Yosef O, Kra RS, editors. Late Quaternary Chronology and Paleoclimates of the Eastern Mediterranean. Tucson: Radiocarbon. p 265-300.

Bliss FJ. 1898. A Mound of Many Cities. 2nd edition. London: Palestine Exploration Fund. 201 p.

Braun E. 2001. Proto, Early Dynastic Egypt, and Early Bronze I-II of the southern Levant: some uneasy ${ }^{14} \mathrm{C}$ comparisons. Radiocarbon 43(3):1279-95.

Bruins HJ. 2001. Near East chronology: towards an integrated ${ }^{14} \mathrm{C}$ time foundation. Radiocarbon $43(3): 1147$ 54.

Bruins HJ, van der Plicht J. 2001. Radiocarbon challenges archaeo-historical time frameworks in the Near East: the Early Bronze Age of Jericho in relation to Egypt. Radiocarbon 43(3):1321-32.

Burton M, Levy TE. 2001. The Chalcolithic radiocarbon record and its use in southern Levantine archaeology. Radiocarbon 43(3):1223-46.

Callaway JA, Weinstein JM. 1977. Radiocarbon dating of Palestine in the Early Bronze Age. Bulletin of the American Schools of Oriental Research 225:1-16.

Dahlberg BT, O'Connell KG, editors. 1989. Tell el-Hesi: The Site and the Expedition. Excavation Reports of the American Schools of Oriental Research: Tell el-Hesi 4. Winona Lake, Indiana: Eisenbrauns. 214 p.

de Miroschedji P. 2000. An Early Bronze Age III pottery sequence for southern Israel. In: Philip G, Baird D, editors. Ceramics and Change in the Early Bronze Age of the Southern Levant. Levantine Archaeology 2. Sheffield: Sheffield Academic Press. p 315-45.
Dever WG. 1997. Ceramics: Syro-Palestinian ceramics of the Neolithic, Bronze, and Iron ages. Volume 1. In: Meyers EM, editor. The Oxford Encyclopedia of Archaeology in the Near East. New York: Oxford University Press. p 459-65.

Doermann RW, Fargo VM. 1985. Tell el-Hesi, 1983. Palestine Exploration Quarterly 117:1-24.

Eakins JK. 1993. Tell el-Hesi: The Muslim Cemetery in Fields $V$ and VI/IX. Excavation Reports of the American Schools of Oriental Research: Tell el-Hesi 5. Winona Lake, Indiana: Eisenbrauns. 214 p.

Esse D. 1991. Subsistence, Trade, and Social Change in Early Bronze Age Palestine. Studies in Ancient Oriental Civilization 50. Chicago: The Oriental Institute of the University of Chicago. $219 \mathrm{p}$.

Fargo VM. 1979. Early Bronze Age pottery at Tell elHesi. Bulletin of the American Schools of Oriental Research 236:23-40.

Golani A, Segal D. 2002. Redefining the onset of the Early Bronze Age in southern Canaan: new evidence of ${ }^{14} \mathrm{C}$ dating from Ashkelon Afridar. In: van den Brink ECM, Yannai E, editors. In Quest of Ancient Settlements and Landscapes. Ramot: Tel Aviv University. p 135-54.

Hennessy JB. 1967. The foreign relations of Palestine during the Early Bronze Age. London: Quaritch. $123 \mathrm{p}$.

Herr LG. 2002. W.F. Albright and the history of pottery in Palestine. Near Eastern Archeology 65:51-5.

Housley RA. 1994. Eastern Mediterranean chronologies: the Oxford AMS contribution. In: Bar-Yosef O, Kra RS, editors. Late Quaternary Chronology and Paleoclimates of the Eastern Mediterranean. Tucson: Radiocarbon. p 55-73.

Mazar A. 2004. Greek and Levantine Iron Age chronology: a rejoinder. Israel Exploration Quarterly 54:2436.

O’Connell KG SJ, Rose DG, Toombs LE. 1978. Tell elHesi, 1977. Palestine Exploration Quarterly 110:7590.

O’Connell KG SJ, Rose DG. 1980. Tell el-Hesi, 1979. 
Palestine Exploration Quarterly 112:73-91.

Petrie WMF. 1891. Tell el-Hesy (Lachish). London: Palestine Exploration Fund. 62 p.

Phillips JL. 1994. The Upper Paleolithic chronology of the Levant and the Nile Valley. In: Bar-Yosef O, and Kra RS, editors. Late Quaternary Chronology and Paleoclimates of the Eastern Mediterranean. Tucson: Radiocarbon. p 169-76.

Rast W. 1992. Through the Ages in Palestinian Archaeology. Philadelphia: Trinity Press International. 221 p.

Reimer PJ, Baillie MGL, Bard E, Bayliss A, Beck JW, Bertrand CJH, Blackwell PG, Buck CE, Burr GS, Cutler KB, Damon PE, Edwards RL, Fairbanks RG, Friedrich M, Guilderson TP, Hogg AG, Hughen KA, Kromer B, McCormac G, Manning S, Bronk Ramsey C, Reimer RW, Remmele S, Southon JR, Stuiver M, Talamo S, Taylor FW, van der Plicht J, Weyhenmeyer CE. 2004. IntCa104 terrestrial radiocarbon age calibration, 0-26 cal kyr BP. Radiocarbon 46(3):1029-58.

Rose DG, Toombs LE. 1976. Tell el-Hesi, 1973 and 1975. Palestine Exploration Quarterly 108:41-54.

Seger JD. 1989. Some provisional correlations in EB III stratigraphy in southern Palestine. In: de Miroschedji $\mathrm{P}$, editor. L'Urbanisation de la Palestine à l'âge du
Bronze ancien: bilan et perspectives des reserches actuelles. BAR International Series 527(i). Oxford: British Archaeological Reports. p 117-35.

Smith WS. 1965. Interconnections in the Ancient Near East. New Haven: Yale University Press. 202 p.

Stager LE. 1992. Palestine. In: Ehrich RW, editor. Chronologies in Old World Archaeology. 3rd edition. Chicago: University of Chicago Press. Volume 1:22-41; Volume 2:17-60.

Stewart RB, Robertson W III. 1971. Moisture and seed carbonization. Economic Botany 25:381.

Stewart RB, Robertson W III. 1973. Application of the flotation technique in arid areas. Economic Botany 27: 114-6.

Toombs LE. 1983. Tell el-Hesi, 1981. Palestine Exploration Quarterly 115:25-46.

Toombs LE. 1990. The joint archaeological expedition to Tell el-Hesi and the results of the earlier excavations. Palestine Exploration Quarterly 122:101-13.

van der Plicht J, Bruins HJ. 2001. Radiocarbon dating in Near Eastern contexts: confusion and quality control. Radiocarbon 43(3):1155-66.

Weinstein JM. 1984. Radiocarbon dating in the southern Levant. Radiocarbon 26(3):297-366. 